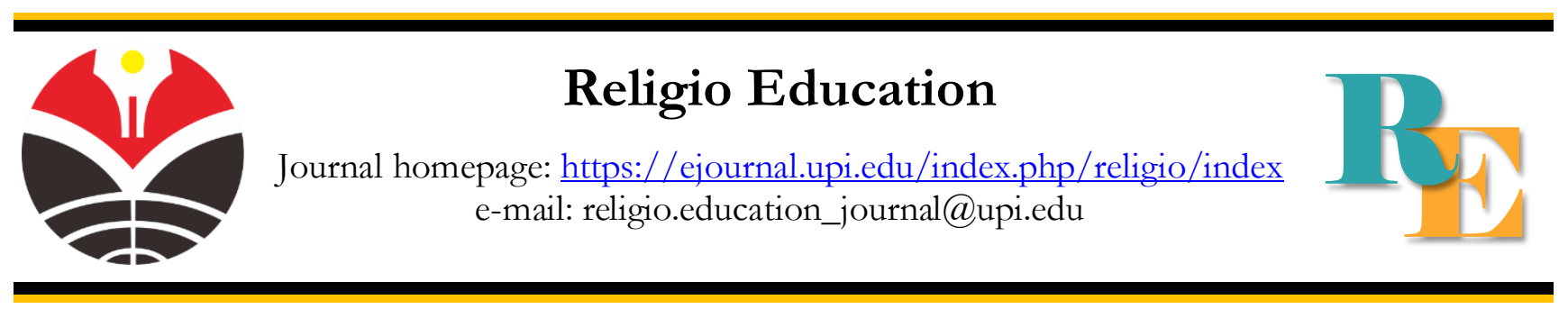

\title{
THE ENHANCEMENT OF ISLAMIC MORAL VALUES THROUGH SEX EDUCATION FOR EARLY CHILDREN IN THE FAMILY ENVIRONMENT
}

\author{
Muqarramah Sulaiman Kurdi* \\ University of Groningen, Groningen, the Netherlands \\ m.s.k.muqarramah@rug.nl \\ Yusmicha Ulya Afif \\ Institut Agama Islam Negeri Ponorogo, East Java, Indonesia \\ yusmicha@iainponorogo.ac.id \\ *Correspondence: m.s.k.muqarramah@rug.nl
}

Abstracts

The fast-moving conditions and development of the times, the easy access to mass media at every level requires that parents provide their children with an education. The education aimed at is sex education for children of an early age. The increasing problem of sexual deviancy behavior in the country of Indonesia is that one is the result of a lack of understanding about sexual education. Sex education should certainly be applied at an early age in order to have good morals and not be susceptible to promiscuity. Premature age is a golden phase for children, treatment of them can affect their life into adulthood. The purpose of research is to learn the importance of sexual education in an early-age child morals based on islamic religious views. A research approach uses a qualitative approach for case study methods. Studies reveal sexual education should be given concurrently with a religious basis. Child sexual education needs to be applied by family members as a protection for their child.
Article Info

Article History:

Received 19 Agustus 2021

Revised 23 September 2021

Accepted 27 Oktober 2021

Available online 15 November 2021

Keyword:

Children's Early Age;

Islam;

Morality;

Sex Education.

\section{Introduction}

Sexual education is an effort to raise awareness, teach, and provide information related to sex issues (Ratnasari \& Alias, 2016). Sex education is included in the aspect of education that must be taught to all children, especially Early Childhood Education. In Article 1 Paragraph 1 of the Law on the National Education System Number 20 of 2003, requires that early childhood is the age of children from newborn to 6 years old. Early age is a golden phase for children. The treatment that must be given to children at this time can affect the lives of children at a later age, even into adulthood. Therefore, sex education should be given to children from an early age. Not only so that sexual education can be embedded in children to adulthood, but also as a shield to protect children from the dangers of sexual harassment and promiscuity. The purpose of early childhood sex education is to give children an understanding that from their physiology, every human being has differences, both male and female. Sexual education does not mean that 
someone learns how to have sex, but sexual education is a teaching whose purpose is to provide an understanding based on facts, discuss honestly and openly, put the meaning of sexuality in the right understanding, relate to self-confidence, also focuses on the ability to act to make decisions (Septiawan et al., 2014). Early childhood sexual education is also very useful for fostering morals in children so that they can prevent social deviations, especially sexual deviations. Early childhood should not be allowed to just look for incorrect information as a result they will have a wrong understanding and imitate what should not be imitated. When viewed from the perspective of educational psychology, the initial foundation for the growth and development of children which is fundamental for future life is at an early age. Early childhood sex education must become a necessity as an effort to assist children in learning and taking preventive measures so that they avoid the sexual violence that is happening today. Considering that mass media is very easy to be accessed by every level of society including children, most access to sexual information on children is obtained through the internet, comic books, television, CDs, playstation, and so on.

In fact, sexual education is still considered taboo by some people, especially when talking about it in front of children, so sexual violence is quite risky for children (Amalia et al., 2018). Some people think that sexual education is still not appropriate for children at an early age. The reason why sex education is still considered unethical is due to the limited understanding that parents and society have regarding sexual education. Basically, a person's knowledge is influenced by internal factors as well as external factors. In internal factors, human knowledge is influenced by age and interests. While in external factors, knowledge is influenced by the family environment, information, education, culture, and an experience. Factors that are very likely to cause sexual education is still considered taboo due to external factors. Parents or the community lack understanding, experience, and information about sexual education in early childhood. Culture is also one of the things that most Indonesian people rely on. They still think that sexual education is a bad thing to talk about in front of their children, so that the culture is passed down from generation to generation. This makes young children do not understand and are encouraged to seek information from others to fulfill their curiosity. If sexual education is not given to children at an early age, then their chances of being sexually abused will be greater because of their ignorance. According to Azzahra in the journal Sex Education Materials for Early Childhood (Suhasmi \& Ismet, 2021), the Indonesian Child Protection Commission (KPAI) said that in early 2018 there were 117 cases of sexual violence that occurred to children, while there were 393 cases throughout 2017. Currently, cases of sexual abuse committed against children continue to increase. Reporting from the Ministry of Women's Protection and Child Protection (KPPA) in 2019 there were 1,500 reports of cases of violence and sexual abuse of Indonesian children. The increase in cases of sexual violence against children is proof of the lack of understanding about sex that they should get from their parents' upbringing. (Sari et al., 2021). In addition to cases of sexual crimes against children, the state of Indonesia is still a monthly media because of the many cases of pregnancy in pre-marital marriages or known as married by accident. This is caused by the promiscuity that occurs in children in this country. Of course this is a serious problem that should not be ignored.

Seeing the rampant cases of sexual violence and promiscuity, it is necessary to hold protection for children. In addition to the legal field, in the field of education there must also be protection for children. In the field of education, things we can do through early childhood sex education. Sexual education should be taught from home and parents are the first teachers. Sex education for children should be given gradually, parents can start from something basic and then move on to the next step. This method must be done because basically the stage of psychological development of each child is different at each age. Apart from parents, the role of the teacher is also one of the important points to provide an understanding of education for 
children at an early age. In schools, teachers can use storybook learning media in which there are pictures as a means of conveying material about sex education for children. Early childhood is very interested in pictures that catch their attention. Teachers together with parents can work together in implementing sexual education for children by conducting parenting activities regarding early childhood sex education. Parenting activity is a program in the field of education that is specifically given to parents so that they know the growth and development of children and anything that children get at home or at school can be aligned (Soesilo, 2021). Parenting activities in schools will make parents more educated about the importance of applying sex education to their children so that they will not consider sex education a foreign thing.

In Islam, sexual education is not new. Islam is a comprehensive religion. Sex education was discussed before the education delegation in 2002, the declaration of A World Fit for Children held in New York. In Islam, education such as faith, morals, and worship is an integrated part and is closely related to sex education. Religion and sex education are two issues that cannot be separated. Sex education must be built entirely on the basis of the Islamic religion. Sex education that is taught in such a way is expected to produce individuals who grow up to be mature individuals and have a sense of responsibility, whether male or female. This is solely so that each individual is able to behave properly according to what should be, able to maintain his purity and adjust himself in a healthy environment. Islam is certainly very concerned about sexual guidance for various ages, because it is part of an integrated education. The initial guidance given must be different from one phase to the next. The main actor to provide sexual guidance for children is in the family sphere. The understanding of sex education in Islam must be accompanied by moral and religious values. Moral is the capital for the development of a child's personality towards maturity because it is part of an integrated education. The initial guidance given must be different from one phase to the next. The main actor to provide sexual guidance for children is in the family sphere. The understanding of sex education in Islam must be accompanied by moral and religious values. Moral is the capital for the development of a child's personality towards maturity because it is part of an integrated education. The initial guidance given must be different from one phase to the next. The main actor to provide sexual guidance for children is in the family sphere. The understanding of sex education in Islam must be accompanied by moral and religious values. Moral is the capital for the development of a child's personality towards maturity (Retno Dwiyanti. 2013). The success of providing an understanding of moral values in children will determine the nature or behavior of a person as an adult. Quoted from the KBBI, morality is a determination of the good and bad behavior of each person. In line with the opinion of (Retno Dwiyanti. 2013)Moral is a way of life that binds us along with the life we live. The main point of moral understanding is the normative rules that must be instilled from an early age by the family or community. It can also be said as good or bad teachings received regarding attitudes or actions. Morals and character have something in common with morals. Indeed, the understanding of sex education that must be taught to early childhood is done so that they can survive the world and the hereafter. In Islam, giving an understanding of sexual education by parents to children is not done verbally, because sexual stimulation arises due to the appearance of certain parts of the opposite sex. Therefore, Islam takes preventive measures from an early age so that the influence of instinctive desires is not harmful to children.

Islam is a revelation that comes down from the sky, meaning that Allah Swt sent religion to the Prophet Muhammad and is universal. Islam is also to complement and perfect the teachings of religions that already exist. An aspect that is quite relevant to the lives of Muslims is the value of education (pedagogical) to guide humans to have a good personality through a directed process, guided by religious teachings whose sources come from the Qur'an and the 
Sunnah of the Prophet. Parents can practice ways that are oriented to what the Prophet exemplified regarding sex education for children.

It aims to prevent negative behavior from children so that they are not directed to crimes or sexual harassment. (Camelia and Nirmala 2017). Early childhood sex education can also foster religious morals for a child. When viewed from an Islamic perspective, by providing an understanding of proper sexuality to early childhood, it certainly leads children to become human beings who can fortify themselves from unscrupulous behavior and become a warning from adulterous behavior as regulated in Islamic teachings. Sex education that is instilled since childhood will have an effect on children in increasing self-confidence, respecting themselves, having healthy thoughts and being people who spread a positive aura (Sari et al. 2021).

Islam strongly encourages parents to always pay attention to the environment around them. Parents are the main parties who play an important role and have the responsibility for the comfort and safety of their children in carrying out the stages of growth and development, both physically, morally, intellectually, and religiously. The application of sexual education in early childhood is the same as applying Islamic teachings to children. As mentioned that planting in Islamic values from an early age is a very essential matter to be able to build spiritual mentality in children in the future (Huda, Syafrida, and Nirmala 2020). If we implement sex education for children from an early age, indirectly they will also instill Islamic values. Islamic values instilled by children is something that will certainly affect the growth and development of children (Parhan and Kurniawan 2020). Instilling Islamic values in children will influence them to think and act in determining what is right or wrong, good or bad behavior or character. Early age is a sensitive period that affects the potential embedded by children so that they will be very easy to absorb information from their parents and teachers. Applying sexual education to children from a young age will form many positive characters in children.

Based on this description, we can see and conclude that sex education is important given to children from an early age. The provision of sexual education for early childhood needs attention from all parties, be it schools, the environment, the government and the most excellent role is the role of parents. This is because children are in a social sphere that cannot be separated from the family and the surrounding community as external factors that can shape one's personality. The delivery of sexual education to early childhood cannot be delivered instantly, but requires a long process and time. This is because children are in a social sphere that cannot be separated from the family and the surrounding community as external factors that can shape one's personality. The delivery of sexual education to early childhood cannot be delivered instantly, but requires a long process and time. This is because children are in a social sphere that cannot be separated from the family and the surrounding community as external factors that can shape one's personality. The delivery of sexual education to early childhood cannot be delivered instantly, but requires a long process and time.

\section{Method}

The approach in this research is a qualitative approach. The method we chose is the case study method. The purpose of using this method is to examine a particular case and discuss it in depth. Data collection was carried out using a questionnaire or questionnaire instrument technique. The use of a questionnaire instrument or questionnaire aims to obtain information about the urgency of sexual education which is an effort to form religious moral awareness of early childhood. Collecting data from this study, respondents are required to answer questions that have been provided by the researcher. All answers obtained from respondents were analyzed to obtain conclusions from the problems being studied. The results of the data obtained were obtained from students, students, teachers, and parents. 


\section{Results and Discussion}

After the researchers distributed the questionnaires, 48 answers were obtained from several respondents' criteria. The research results will be explained as follows: From the results of distributing questionnaires through Google Forms, the criteria for respondents in this study were grouped based on 4 criteria, namely students, parents, teachers, and housewives. Based on the questionnaires that have been distributed, there are 48 respondents who have filled out the results with $50 \%$ or 24 students, $45.8 \%$ or 22 parents, $2.1 \%$ or 1 teacher, and $2.1 \%$ or 1 housewife. $41 \%$ or 20 people think sex education is something that is prohibited from being discussed or is still considered a taboo in their family, 35.4\% or 17 people think sex education is not taboo in their family, and $22.9 \%$ or 11 people answer may consider sex education a taboo in their family. $81.3 \%$ or 39 people think that sex education should be applied to early childhood, $14.6 \%$ or 7 people think that sex education should probably be applied to early childhood, and $4.2 \%$ or 2 people think that sex education is not should be applied to children at an early age.Respondents who answered yes, they thought that the growing growth of a child needed to be accompanied by knowledge of many things, one of which was about sex. Not only introducing the reproductive organs in their bodies, sexual education is also needed to take care of themselves so that when they grow up, they can act more carefully and know the difference between their boundaries regarding what is natural and what is not in making friends with people. opposite sex and take better care of themselves in the future. Respondents who answered maybe, they think that sex education aims for children to have a foundation to live and love and respect themselves by taking care of what must be protected. Meanwhile, respondents who answered no, thought that it was not the time for early childhood to be taught sex education. $52 \%$ or 25 people said they had never been asked about sex education by early childhood, while $47.9 \%$ said they had never been asked about it. Respondents who answered yes, they answered questions using words that could be understood by children, while respondents who answered no, they were never asked questions about sexual education by early childhood. $54.2 \%$ or about 26 people may agree that teenagers who are influenced to promiscuity are the result of lack of sex education at an early age, $41.7 \%$ or 20 people agree, and $4.2 \%$ or 2 people disagree with this opinion.

Respondents who answered yes, they said it was because many teenagers did not know information about the dangers of promiscuity, such as drug addicts, having free sex, and so on. Respondents who answered maybe, said there were many reasons why teenagers fell into promiscuity such as being influenced by western culture, the surrounding environment and maybe sexual education that was not taught from an early age was one of the causes. While respondents who answered no, they said it was the influence of the environment. $79.2 \%$ or 38 people know that Islam regulates sex education in early childhood, $16.7 \%$ or 8 people may know, and $4.2 \%$ or 2 people do not know Islamic rules regarding sex education in early childhood.

Respondents who answered yes, they said that Islam teaches us to keep the boundaries between men and women also teaches us to control our lusts. Islam also teaches to stay away from the intention of adultery, so that children understand how to stay away from adultery, therefore there must be education related to sex. Respondents who answered maybe, they said that even the prohibition of revealing aurat in Islam is included in sex education. While respondents who said no, they said Islam does not recommend sex education for early childhood. $77.1 \%$ or 37 people think that sex education has an influence on children's religious morals, $16.7 \%$ or 8 people think that sex education may have an effect, and $6.3 \%$ or as many as 3 people think that sex education has no effect on religious morals child.

Respondents who answered yes, they said that sexually educated children know what is right and wrong, and will definitely stay away from what is wrong. This is in line with religious provisions. With sexual education, children will be able to prepare themselves for the future, 
take care of themselves properly by covering their genitals and have provisions for children to grow up in the future. Respondents who answered maybe, they said that maybe knowing their child's sexual education would be more respectable. While respondents who answered no, they said that religious morals had nothing to do with sex education in early childhood.

Based on the answers from respondents regarding the views and opinions regarding the urgency of sex education for early childhood, it was found that sex education is the provision of information about understanding human reproduction, reproductive health, human anatomy and physiology, and boundaries between the opposite sex (Mukti 2016). Sex education is something that must be applied to early childhood so that they avoid cases of sexual harassment. Providing an understanding of sex education in early childhood must be adjusted according to age. Sex education in early childhood does not mean explaining how to have sex between men and women, but rather how to understand oneself as someone who has been created by Allah, both as a woman and as a man.

We know that in the last six years, there have been more than 1,500 case reports that were reported to the KPAI, there were 227 cases of rape and 128 cases of sexual harassment. The actual number that occurs in the community is very high, because many women are hesitant to complain about cases of rape or sexual irregularities that they have experienced (Justicia 2017). This case was caused by a lack of understanding about sex education which should have been instilled in early childhood. From the questionnaires that have been distributed, most of the respondents answered that sex education for an early age is very urgent to be implemented as a provision for them in the future. But on the one hand, sex education for early childhood is still something that is taboo by society because it is considered unethical if it is discussed in front of parents. This is because there are several obstacles experienced by parents when they will provide an understanding of sex education to their children. Parents are afraid that if their child receives a wrong understanding or misperception, the child will have difficulty understanding because of the limited use of the language used by their parents,

Sex education for children at an early age must be delivered in accordance with their age and parents who have an important role in delivering sex education are parents, because they are the people closest to children. When sex education has been given at home by parents, a teacher in a formal institution can also help provide an understanding of sex education. But the problem is that parents' understanding of sex education in early childhood is still lacking and causes not all of them to know the importance of early childhood sex education. The level of understanding of parents related to sex education for an early age is influenced by several factors including age, culture, education, experience, information, and work, and others (Hety 2017). There is a difference in knowledge between parents regarding early childhood sex education, an effort that can be done is by carrying out parenting sex education activities which are usually carried out in schools. Parenting activities are expected to be able to encourage optimal physical, mental and social growth. Parenting is the habituation of the interaction or socialization process carried out by parents and children (Soesilo 2021).

An introduction to the understanding of sex to have some material in it. The introduction of sex education in children should start with identifying the parts of the body in children which will be introduced to other materials (Suhasmi and Ismet 2021). In sexual education, children will be taught about the naming of their body parts and the differences between their limbs and members of the opposite sex. There are several efforts by parents in understanding the concept of sexual education in children, including through guessing games, fun sexual education spectacles, and through songs. In addition to introducing members of the body, early childhood can also be given an understanding of the differences in the nature of a man and a woman. For example, getting used to children praising their fathers and mothers as "handsome father", "beautiful mother", and so on. Children can also be given an understanding 
of the differences in physical characteristics between boys and girls, such as boys with short hair and girls with long hair.

Islam has clearly provided rules regarding the provision of sex education to children. Sexual education itself in Islam is a unity of aspects of aqidah, worship, and morals (Parhan et al. 2021). If the provision of sex education to children is not based on these three aspects, then the sexual education provided will experience a lack of clarity (Kasmini and Fajriah 2016). Worse still, this may violate Islamic religious rules. Sex education can begin to be taught to children when children already know the difference between themselves and other children, both of different ages and of different genders. The provision of sex education to early childhood according to Islam can be given in several ways, including maintaining aurat, separating children's beds, getting children to ask permission when entering parents' rooms, teaching a culture of shame, teaching defecation etiquette, and instilling a masculine soul in children. boys and femininity in girls.

Sex education is related to the religious moral growth of children. We can see this from the impact of sex education that can keep children away from bad deeds. If a child can stay away from bad deeds, he will try to always do good deeds. Good deeds will produce good morals, good morals produce good thoughts, good thoughts produce good habits, good habits produce commendable character, commendable character produces righteous deeds, and righteous deeds can bring children closer to Allah Swt. Meanwhile, if a child is not given proper sex education, then the child is easier to do bad deeds. If a child continues to do bad deeds, it will produce bad morals, bad morals produce bad thoughts, Bad thoughts produce bad habits, bad habits produce despicable characters, despicable characters produce bad behavior, and bad behavior can keep children away from Allah Swt. Based on this explanation, it is clear that sex education and religious morals are interrelated and complement each other. If children are given sex education, morals and religion will automatically become the basis of that education. Thus, children's religious morals also grow along with their understanding of sex education. Islam has provided clear guidelines for its followers on how to provide sexual education to children from an early age.

There are several ways to provide an understanding of sex to children in Islam according to Islam and bad behavior can keep children away from Allah Swt. Based on this explanation, it is clear that sex education and religious morals are interrelated and complement each other. If children are given sex education, morals and religion will automatically become the basis of that education. Thus, children's religious morals also grow along with their unders tanding of sex education. Islam has provided clear guidelines for its followers on how to provide sexual education to children from an early age. There are several ways to provide an understanding of sex in children in Islam according to Islam and bad behavior can keep children away from Allah Swt. Based on this explanation, it is clear that sex education and religious morals are interrelated and complement each other. If children are given sex education, morals and religion will automatically become the basis of that education. Thus, children's religious morals also grow along with their understanding of sex education. Islam has provided clear guidelines for its followers on how to provide sexual education to children from an early age. There are several ways to provide an understanding of sex in children in Islam according to Islam automatically morals and religion will be the basis of the education. Thus, children's religious morals also grow along with their understanding of sex education. Islam has provided clear guidelines for its followers on how to provide sexual education to children from an early age. There are several ways to provide an understanding of sex in children in Islam according to Islam automatically morals and religion will be the basis of the education. Thus, children's religious morals also grow along with their understanding of sex education. Islam has provided clear guidelines for its followers on how to provide sexual education to children from an early age. 
There are several ways to provide an understanding of sex in children in Islam according to Islam (Mukti 2018), as follows: 1) Keeping Aurat, Allah has facilitated humans with clothes to cover their genitals. Covering the genitals is one of the efforts to keep children away from sexual deviations. In addition to covering the genitals, humans are also commanded by Allah to guard their eyes and genitals. 2) Separating Children's Beds, Prophet Muhammad saw ordered Muslims to be able to separate their children's beds, both separated from their parents and siblings. This command applies to children who are approaching the age of puberty. 3) Familiarizing Children Asking Permission When Entering Parents' Room, child must ask permission when entering the parent's room in three times, the time in question is before worshiping at dawn, in the afternoon, and after the Isha prayer. That's because at these three times, the parents are probably at the time when their genitals are exposed. 4) Teaching Shame Culture, forbidden for a boy or a girl to be in the same blanket as another person, even if they are of the same sex. This data prevents children from the possibility of adultery and having sexual deviations.5) Teaching Toilet Etiquette (Toilet Training), Prophet Muhammad saw gave an understanding of maintaining genital hygiene, especially when defecating. This data prevents children from having dangerous venereal diseases. 6) Instilling the Spirit of Masculinity in Boys and the Spirit of Feminism in Girls, Prophet Muhammad saw forbade, even cursed a man who imitates a woman and a woman who imitates a man. This is a prevention for children, so that they are not confused about their nature which can lead to sexual deviations in the future. ElQudsy shares various strategies that can be done to provide an understanding of early childhood sex, namely by strengthening or deepening the understanding of Islamic religious education, starting to understand the true meaning of sex from an early age, providing an understanding of sex according to age and what is needed by children, can be done gradually and continuously, and parents should not avoid being asked by the child.

\section{Conclusion}

Sex education for early childhood does not mean teaching children to have sex, but rather providing understanding and information to children regarding sex issues, the natural function of sex as part of a person's self and the consequences if it is played with. In this case, parents as the main handle or important actor to provide sex education to children. Some people in Indonesia still think that giving children an understanding of sex is unethical. When it is considered prohibited (taboo) it will facilitate the occurrence of sexual deviations or crimes. Lack of provision about sex that does not start when children are at an early age will carry over when they are adults. Teenagers will find out various kinds of information regarding sex because of their curiosity. If the information obtained is not true then they tend to do actions that should not be imitated. Based on the results of research regarding the urgency of early childhood sex education, it was found that the provision of understanding of sex education for early childhood must be adjusted according to age. Parents must endure feelings of awkwardness or embarrassment when teaching their children about sex. Islam strongly encourages parents to always pay attention to the environment around them. In Islam, faith, morals, worship are an integrated part and are closely related to sex education. Religion and sex education are two issues that cannot be separated. Sex education must be built entirely on the basis of the Islamic religion and is also related to the religious moral growth of children. This can be seen from the impact of sex education that can keep children from bad deeds. If a child can stay away from bad deeds, he will try to always do good deeds. Good deeds will produce good morals, good thoughts, good habits, commendable character, and have good deeds, righteous deeds can bring children closer to Allah Swt. 


\section{References}

Abidin, A. A., \& Luthfi, M. (2016). Urgensi Pendidikan Seks pada Siswa Madrasah Ibtidaiyah dalam Upaya Pencegahan Perilaku Penyimpangan Seksual di Kabupaten Jombang. Jurnal Ilmiah Didaktika: Media Ilmiah Pendidikan dan Pengajaran, 17(1), 18-37. doi: http://dx.doi.org/10.22373/jid.v17i1.1587

Amalia, E., Afdila, F. L., \& Andriani, Y. (2018). Pengaruh Pemberian Pendidikan Seksual Terhadap Kejadian Kekerasan Seksual Pada Anak Di Sd Negeri 04 Balai Rupih Simalanggang Payakumbuh Tahun 2018. JURNAL KESEHATAN PERINTIS (Perintis's Health Journal), 5(2), 162-168. https://doi.org/10.33653/jkp.v5i2.125

Ananda, R. (2017). Implementasi Nilai-nilai Moral dan Agama Pada Anak Usia Dini. Jurnal Obsesi: Jurnal Pendidikan Anak Usia Dini, 1(1), 19-31. doi: 10.31004/obsesi.v1i1.28

Camelia, L., \& Nirmala, I. (2017). Penerapan Pendidikan Seks Anak Usia Dini Menurut Perspektif Islam. Pendidikan Anak Usia Dini, 1, 27-32. https://jurnal.umj.ac.id/index.php/YaaBunayya/article/view/1720/1449

El-Qudsy, H. 2012. Ketika Anak Bertanya tentang Seks: Panduan Islami bagi Orang tua Mendampingi Anak Tumbuh menjadi Dewasa. Solo: Tinta Medina.

Hety, D. S. (2017). Pengetahuan Orang Tua Tentang Pendidikan Seks Dini Pada Anak Usia Pra Sekolah (3-6 Tahun) Di Tk Tunas Jayabangsal Mojokerto. Animal Behaviour, 69(2), 283291. doi: https://doi.org/10.5281/zenodo.3514532

Huda, L., Syafrida, R., \& Nirmala, I. (2020). Menanamkan Nilai-Nilai Islami Pada Anak Usia Dini 3-6 Tabun Melalui Metode Bermain Peran.4(2), 181-191.

Inawati, A. (2017). Strategi Pengembangan Moral dan Nilai Agama untuk Anak Usia Dini. AlAthfal: Jurnal Pendidikan Anak, 3(1), 51-64.

Jannah, M. (2017). Remaja dan Tugas-tugas Perkembangannya dalam Islam. Psikoislamedia: Jurnal Psikologi, 1(1). 243-256. doi: http://dx.doi.org/10.22373/psikoislamedia.v1i1.1493

Justicia, R. (2017). Pandangan Orang Tua Terkait Pendidikan Seks Untuk Anak Usia Dini. Early Childhood: Jurnal Pendidikan, 28-37. https://doi.org/10.35568/earlychildhood.v1i2.121

Kasmini, L., \& Fajriah, M. P. (2016). Pendidikan Seks Bernuansa Islam Untuk. Anak Usia Dini.

Kustiawan, U. (2016). Pengembangan Media Pembelajaran Anak Usia Dini. Penerbit Gunung Samudera [Grup Penerbit PT Book Mart Indonesia].

Mahluzatin, E. (2016). Persepsi Orang Tua Tentang Pendidikan Seks Anak Usia Dini (Doctoral dissertation, UIN Sunan Ampel Surabaya).

Mukri, S. G. (2018). Pendidikan Seks Usia Dini dalam Perspektif Hukum Islam. Mizan: Journal of Islamic Law, 3(1). 1-20. doi: https://doi.org/10.32507/mizan.v3i1.153

Mukti, A. (2018). Pendidikan Seks Untuk Anak Usia Dini Perspektif Islam. Jurnal Harkat: Media Komunikasi Gender, 12(2), 89-98. https://doi.org/10.15408/harkat.v12i2.7562

Parhan, Muhamad, and Dara Puspita Dewi Kurniawan. 2020. "Aktualisasi Peran Ibu Sebagai Madrasah Pertama Dan Utama Bagi Anak Di Era 4.0.” JMIE (Journal of Madrasah Ibtidaiyah 
Education) 4(2):157. doi: 10.32934/jmie.v4i2.193.

Parhan, Muhamad, Usup Romli, Mohammad Rindu Fajar Islamy, and Salima Muhammad Husein. 2021. "MEDIA LEARNING AQIDAH THROUGH THE TADARUZIAH WAQI'IAH APPROACH FOR ELEMENTARY SCHOOL STUDENTS IN BANDUNG.” Didaktika Religia 9(1):101-120. doi: 10.30762/didaktika.v9i1.3165.

Nawangsari, D. (2015). Urgensi Pendidikan Seks dalam Islam. TADRIS: Jurnal Pendidikan Islam, 10(1), 74-89. doi: 10.19105/jpi.v10i1.639

Ratnasari, R. F., \& Alias, M. (2016). Pentingnya Pendidikan Seks untuk Anak Usia Dini. Jurnal Tarbawi Khatulistiwa, 2(2), 55-59. https://doi.org/http://dx.doi.org/10.29406/.v2i2.251

Retno Dwiyanti. (2013). Peran Orang Tua Dalam Perkembangan Moral Anak (Kajian Teori Kohlberg). Prosiding Seminar Nasional Parenting, 161-169. http://hdl.handle.net/11617/3983

Sari, A. I. C., Karlina, E., \& Rasam, F. (2021). Penyuluhan Pendidikan Seks dan Mengenal Masa Golden Age pada Anak Usia Dini di TKIT Al-Faqih. KANGMAS: Karya Ilmiah Pengabdian Masyarakat, 2(1), 1-8. https://doi.org/10.37010/kangmas.v2i1.72

Septiawan, Haris, Pitoewas, Berchas, Yanzi, H. (n.d.). PENGARUH PENDIDIKAN SEKS D ALAM KELUARGA TERHAD AP PERKEMBANGAN MORAL ANAK. 148,148162.

Setiawan, R., \& Nurhidayah, S. (2008). Pengaruh Pacaran Terhadap Perilaku Seks Pranikah. SOUL: Jurnal Pemikiran dan Penelitian Psikologi, 1(2), 59-72.

Soesilo, T. D. (2021). Pelaksanaan Parenting Pendidikan Seks (Pesek) Anak Usia Dini di PAUD Tunas Bangsa Ungaran Kabupaten Semarang. Scholaria: Jurnal Pendidikan Dan Kebudayaan, 11(1), 47-53. https://doi.org/10.24246/j.js.2021.v11.i1.p47-53

Suhasmi, N. C., \& Ismet, S. (2021). Materi Pendidikan Seks Bagi Anak Usia Dini. Jurnal Golden Age, Universitas Hamzanwadi, 5(02), 164-174. doi: https://doi.org/10.29408/goldenage.v5i01.3486

Susmiarsih, T. P., Marsiati, H., \& Endrini, S. (2019). Peningkatan Pengetahuan Faktor-faktor yang Memengaruhi Perilaku Seks dalam Upaya Cegah Seks Pranikah pada Siswa-siswi SMP N 77 dan SMA N 77 Jakarta Pusat. Jurnal Pengabdian kepada Masyarakat (Indonesian Journal of Community Engagement), 4(2), 206-213. doi: 10.22146/jpkm.34197

Sumera, M. (2013). Perbuatan Kekerasan/Pelecehan Seksual Terhadap Perempuan. Lex et Societatis, 1(2). doi: https://doi.org/10.35796/les.v1i2.1748

Suryana, D. (2016). Pendidikan Anak Usia Dini: Stimulasi \& Aspek Perkembangan Anak. Prenada Media.

Umroh, I. L. (2019). Peran Orang Tua Dalam Mendidik Anak Sejak Dini Secara Islami Di Era Milenial 4.0. Ta'lim: Jurnal Studi Pendidikan Islam, 2(2), 208-225. Retrieved from http://ejurnal.unisda.ac.id/index.php/talim/article/view/1644

Winarti, A. (2020). Implementasi Parenting Pada Pendidikan Anak Usia Dini di Masa Pandemi Covid-19. Jp3m: Jurnal Pendidikan, Pembelajaran Dan Pemberdayaan Masyarakat, 2(2), 131-145. doi: https://doi.org/10.37577/jp3m.v2i2.272 
Zubaedah, S. (2016). Pendidikan Seks pada Anak Usia Dini di Taman Kanak-kanak (TK) Islam Kota Yogyakarta. Al-Athfal: Jumal Pendidikan Anak, 2(2), 55-68. Retrieved from http://ejournal.uin-suka.ac.id/tarbiyah/alathfal/article/view/1267

Zulfah, M. A. (2017). Pendidikan Seks pada Anak dalam Islam. Studi Islam dan Muamalab At Tabdrib, 150-171. Retrieved from: http://ejournal.kopertais4.or.id/mataraman/index.php/tahdzib/article/view/2921 